\title{
Challenges to the sustainable use of water resources in the Ili River basin of Central Asia
}

\author{
Sabir Nurtazin ${ }^{1}$, Niels Thevs ${ }^{2}$, Margulan Iklasov ${ }^{1}$, Norman Graham $^{3}$, Ruslan Salmurzauli ${ }^{1}$, and \\ Steven Pueppke ${ }^{3, *}$ \\ ${ }^{1}$ Biology and Biotechnology, Al-Farabi Kazakh National University, Almaty, Kazakhstan \\ ${ }^{2}$ World Agroforestry Centre, University of Central Asia, Bishkek, Kyrgyzstan \\ ${ }^{3}$ CERES, Michigan State University, East Lansing, MI USA
}

\begin{abstract}
Water is a scarce resource in Central Asia, and many catchments span international boundaries, among them that of the lli River, which is shared by China and Kazakhstan. Since 1970, the natural hydrological regime of the lli River, both absolute flow rates and cycles, has changed due to construction of reservoirs such as that at Kapchagai, as well as natural climatic cycles and the growth of water consumption in the basin. Using data from Kazhydromet, we calculated that flow rates below Kapchagai dam averaged $468 \mathrm{~m}^{3} / \mathrm{sec}$ before construction of the dam, $366 \mathrm{~m}^{3} / \mathrm{sec}$ while the reservoir was being filled, and $489 \mathrm{~m}^{3} / \mathrm{sec}$ between 1988 and 2013. The dam has profoundly altered the annual cycle of flows in the river, with reductions in the summer and increases in the winter, when water is released to produce hydropower. The effects of these changes are being heightened by China's increasing diversion of the river's water. The sustainable use of decreasing water resources to conserve the biodiversity of the Ili-Balkhash basin's ecosystems mandates a solution to the water allocation challenge between China and Kazakhstan. This will require a basin-wide approach that includes modernization of water distribution systems and careful consideration to relative priority needs for food, hydropower, and communal uses in both countries.
\end{abstract}

\section{Introduction}

Regulating the use of transboundary watercourses is one of the most pressing issues related to the problem of water resources today [1], and nowhere are these challenges more acute than in Central Asia, where the most inefficient water consumer is irrigated agriculture [2]. Water losses in Central Asia's irrigation systems can reach $50-70 \%$ of the incoming volume, with evaporation in the main irrigation zone reaching 1,500-2,000 $\mathrm{mm}$ per year. Diversion of water to generate hydropower also consumes water, much of which is lost to seepage and evaporation from impoundments $[3,4]$.

The risks and threats associated with the growing water deficit in Central Asia are especially relevant for the Republic of Kazakhstan, the largest territory $\left(2.7\right.$ million $\left.\mathrm{km}^{2}\right)$ in the region. Scarcity of fresh water is the most acute environmental problem hampering the country's sustainable development and stands as Kazakhstan's fourth most important global challenge for the $21^{\text {st }}$ century [5]. The trend in total volume of river flow in Kazakhstan is unmistakably downward. After the high water in the $1940 \mathrm{~s}$, when total flow was estimated at $150 \mathrm{~km}^{3} / \mathrm{year}$, it fell in the 1970s and 1980 s to $115-125 \mathrm{~km}^{3} /$ year, and then in 2000 to $100.5 \mathrm{~km}^{3} /$ year [6]. Slightly more than half of the total flow is from sources within Kazakhstan, with the remainder coming from China, Uzbekistan, Kyrgyzstan, and Russia [7].

The most threatened river in highly populated southeastern Kazakhstan is the Ili, a transboundary river that arises from the Kash, Tekes, and Künes rivers of Xinjiang Province,

\footnotetext{
* Corresponding author: pueppke@msu.edu
} 
China (Figure 1), and flows through a rich delta before delivering $70-80 \%$ of the total inflow into terminal Lake Balkhash $[8,9]$. The catchment area is about $140,000 \mathrm{~km}^{2}$, and although $55 \%$ of this area lies in Kazakhstan, it contributes only $20-30 \%$ of the inflows entering the Ili River [10]. The river is mountain-sourced and predominantly fed by glacier-snow melt that occurs at altitudes above 2,000 meters in the Tian Shan mountains. The basin of the Ili River is influenced by precipitation in the warm period, which is especially abundant $(800-1,200 \mathrm{~mm} / \mathrm{year})$ in the high-altitude mountains [11].

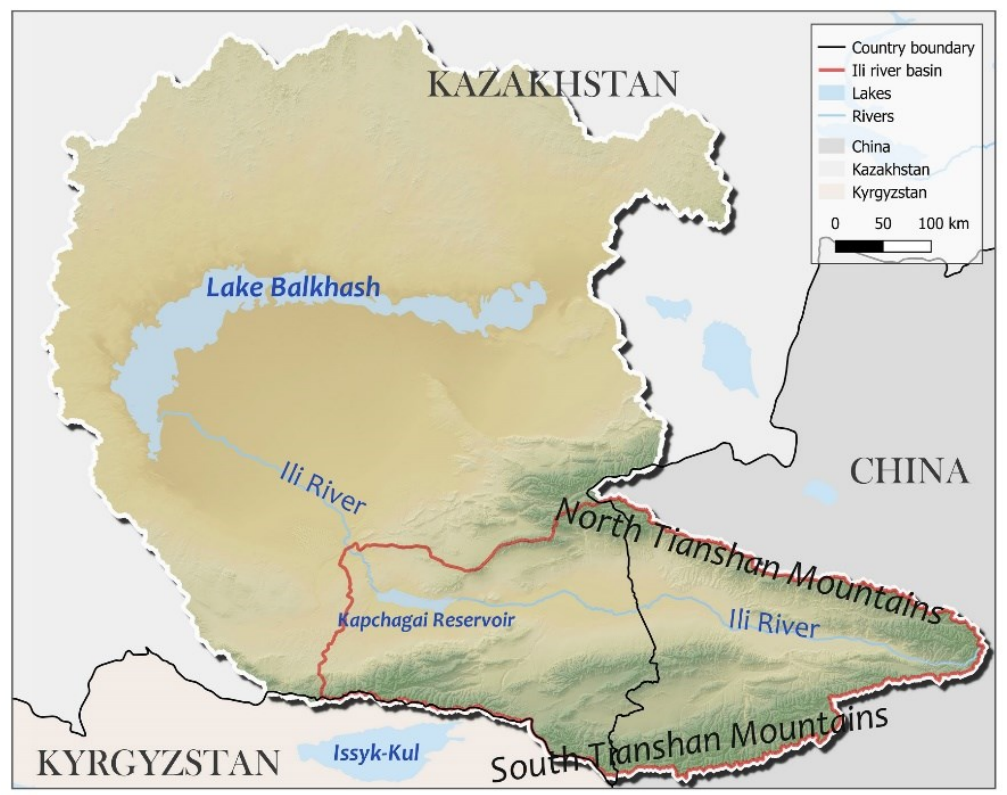

Fig. 1. Map of the Ili River basin, which encompasses all of the Chinese portion of the larger Ili-Balkhash basin, as well as southeastern portions of the Ili-Balkhash basin (including Kapchagai Reservoir) in Kazakhstan.

\section{Hydrological changes associated with dam construction}

The Ili River flowed naturally until Kapchagai dam and reservoir were constructed by the Soviets to produce energy and collect water for irrigation. The dam was closed at the end of December 1969, and the reservoir began to fill to a planned total volume of $28 \mathrm{~km}^{3}$, which was equivalent to almost twice the total annual inflow of the river $[3,8,10]$. In reality, the target level of the reservoir, $485 \mathrm{~m}$ above sea level, and the corresponding surface area, $1,847 \mathrm{~km}^{2}$, were greatly overestimated and never achieved. As the predicted detrimental impacts on the delta and Lake Balkhash became apparent [8], the water level was kept below $477.6 \mathrm{~m}$ above sea level, so that the reservoir's area has not exceeded 1,275-1,280 $\mathrm{km}^{2}$, and its volume has remained less than $16.5 \mathrm{~km}^{3}$ [12]. 
Beginning in 1970, an abrupt and persistent $20-25 \%$ decrease in flow was detected at the Kapchagai hydropost, which is situated $37 \mathrm{~km}$ downstream from the dam and hydroelectric power station $[4,9,13]$. About one-third of this decrease has been attributed to human activity and the rest to natural variability, i.e. the onset of a cycle of low river flow. The average annual flow of the Ili River over the multi-year, pre-dam period from 1929-1969 was $14.7 \mathrm{~km}^{3}$ (467 $\mathrm{m}^{3} / \mathrm{sec}$ ) as measured by Kazhydromet at the Kapchagai hydropost. Of this, inflows from China as measured at the Kaijergan hydropost near the border contributed $12.3 \mathrm{~km}^{3}$, and groundwater recharge and inflows from Kazakhstan added the remaining $2.4 \mathrm{~km}^{3}$. The corresponding average annual flow of the river during the interval from 1970 to 1987 , when the reservoir was being filled, was reduced to $11.7 \mathrm{~km}^{3}\left(372 \mathrm{~m}^{3} / \mathrm{sec}\right)$. During this interval, lower inflows from China and withdrawal of water into the reservoir were only partially offset by increased inflows from within Kazakhstan.

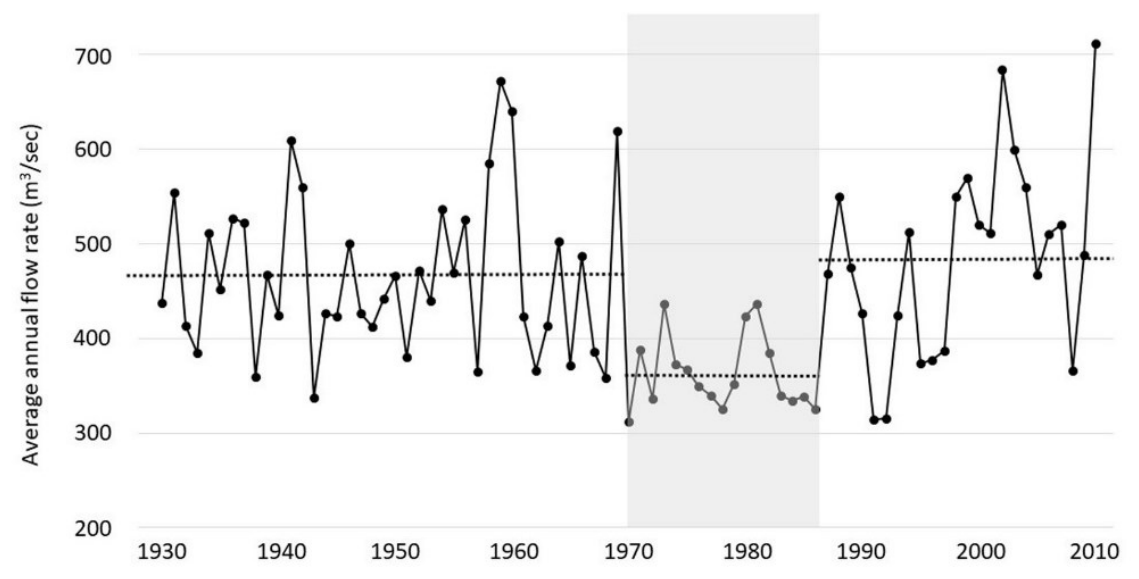

Fig. 2. Annual average runoff of the Ili River at the Kapchhagai hydropost. From left to right, the horizontal dotted lines indicate the average runoff for the period before dam construction, during filling of the reservoir (shaded area), and thereafter. Data are from Kazhydromet.

Figure 2 charts the annual discharge of the Ili River below the reservoir at the Kapchagai hydropost for a 40-year period preceding construction of the dam and two intervals thereafter. The average flow rate for the baseline period prior to dam construction was $468 \mathrm{~m}^{3} / \mathrm{sec}$. The first post-dam interval corresponds to the time during which water from the river was being diverted annually to fill the impoundment (Figure 2, shaded area). Annual flow rates during this period were fairly constant and averaged $366 \mathrm{~m}^{3} / \mathrm{sec}$, a $22 \%$ reduction compared to the baseline. The second interval corresponds to a 23-year after which diversion of water to fill the reservoir had ceased. The average flow rate during this interval, $489 \mathrm{~m}^{3} / \mathrm{sec}$, was slightly higher than that during the baseline period. This interval is also characterized by a trend toward increasing flows that correlates with rises in the level of Lake Balkhash and has been attributed to the onset of a period of favorable environmental conditions [2]. Our data show that two of the three years with the highest flow rates over the past eight decades occurred early in the twenty-first century.

Figure 3A shows that under the natural conditions prevailing between 1950 to 1969, Ili River flows at the Kapchagai hydropost underwent a seasonal cycle. Flow rates during the summer months of June, July, and August (shaded area) exceeded those during the winter months of December, January, and February by a factor of three or more. Elevated summer flows corresponded to the time of most intensive melting of snowfields and glaciers, and they subsided 
as air temperatures began to cool in the fall. Water levels dropped throughout the autumn months, eventually returning to the low flows characteristic of winter.

Figure 3B contrasts this natural pattern of monthly flow rates with those experienced during two subsequent intervals: the years when water was being withheld to fill the reservoir (1970$1987)$ and the subsequent years when the reservoir was no longer being filled (1988-2013) and the environment was favorable [13]. It is apparent that the natural pattern was altered during both of these time intervals such that less water flowed during the summer months and more during the winter. Thus, in comparison to the baseline period, flows during June, July, and August of 1970-1987 and 1988-2013 were decreased by 40-50\% and 25-30\%, respectively. Corresponding increases in winter flows are evident for both time intervals but were of greater magnitude during the 1988-2013 period.

These changes reflect the impoundment of summer floodwaters behind the dam and high levels of discharge through the dam's turbines to generate energy for heat during the cold winter months. Daily oscillations also occurred, and peak surges were as much as $1,000 \mathrm{~m}^{3} / \mathrm{sec}$. This led to counter-seasonal floods, with waves sometimes reaching a height of $0.5 \mathrm{~m}$ between the dam and the upper reaches of the delta, causing ice flow, congestion, and numerous spills onto land that did not normally flood [14]. This and continued shortages of water in the summer have affected downstream communities and the ecosystem's biota [10]. The consequences have been serious, not just for the lake, but also for the health of the delta, which is dependent on fluctuating water levels conditioned by periodic natural flooding [15].

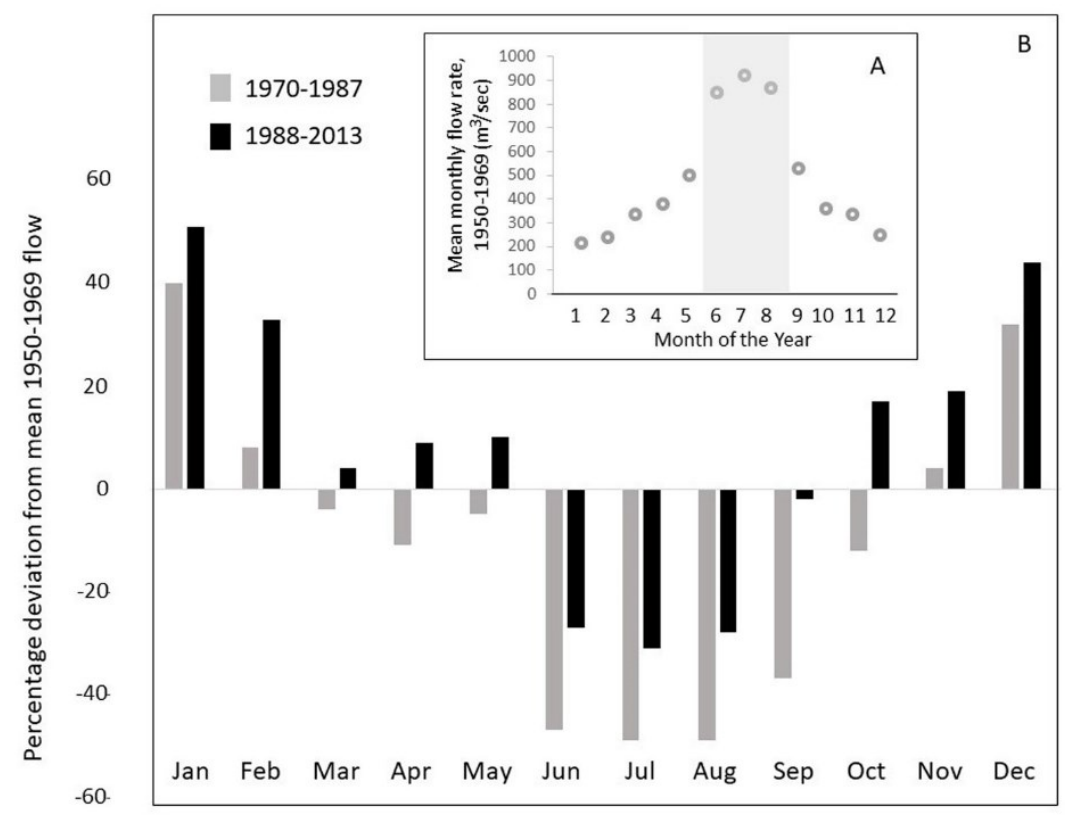

Fig. 3. (A) Average monthly water flow of the Ili River under natural conditions during a 20-year period prior the closure of the Kapchagai Dam (1950-1969). The shaded area indicates the high flow months of June, July, and August. (B) Average monthly flow rates during the filling of the reservoir (1970-1987) and thereafter (1988-2013). Flow rates are given as percentage deviation from the corresponding mean rates measured during the 20-year baseline prior to construction of the dam. Measurements were taken at the Kapchagai hydropost and are from Kazhydromet.

The construction of Kapchagai dam and reservoir almost a half century ago has been followed more recently by another set of changes associated with the rapid economic development along the upper reaches of the Ili River and its headwaters in China's Ili Autonomous Kazakh Prefecture [16]. These waterways flowed relatively freely prior to the late 1980s, when 
construction of dams and reservoirs began [9]. There are currently eight major dams, four on the Kash River and four on the Tekes River; most serve dual functions for production of hydroelectric energy and water for irrigation. Dozens of smaller reservoirs have also been built on the Chinese territory of the Ili River basin [17]. Although most reservoirs lie upstream in China, the largest of these impounds only an estimated 1,650-1,800 million cubic meters of water. Although their total estimated volume is equivalent to less than one-quarter that of the Kapchagai reservoir in Kazakhstan, these impoundments nevertheless are already perturbing seasonal flows into the upper Ili River [18] as irrigation expands. Figure 4 illustrates the extent of irrigation on the Chinese side of the border, just south of the Ili River.

\section{Perspectives for the future}

Water security for southeastern Kazakhstan is narrowly based in a geographical sense and heavily dependent on inflows from China. The future distribution of Ili River water is thus a matter of immense strategic importance for both countries and has been the subject of numerous negotiations spanning almost a quarter century [19, 20, 21]. Kazakhstan's position in these negotiations remains precarious, because China, a much larger and more powerful country, controls the upper reaches of the basin. Indeed, China rejected Kazakhstan's 2007 offer to exchange free or heavily discounted food for a commitment to allow the river to flow unimpeded into Lake Balkhash.

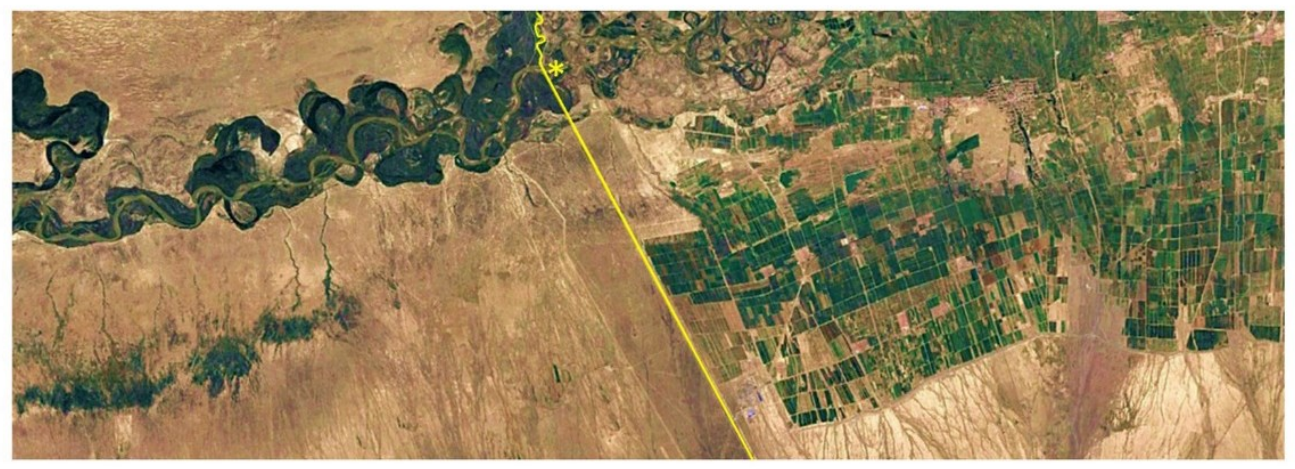

Fig. 4. Satellite image from 2014 of the area where the Ili River flows westward from China into Kazakhstan. The border is indicated, and the river crossing is marked with an asterisk. The river and riparian vegetation are clearly demarcated from the surrounding arid landscape in Kazakhstan. Irrigated fields extending to the border are visible on the Chinese side. Source: Google Earth.

Although exercise of sovereignty and maintenance of internal food and water security appear to be of more importance to China than the ecology of the Ili-Balkhash basin as a whole, China's Belt Road Initiative may signal a new era of cooperation. China is financing the construction of pipelines, high speed rail lines, and highways through a new transportation corridor that crosses Kazakhstan's portion of the Ili-Balkhash basin, close to the path of a supply route that was used during World War II. An expansive new dry port and international trade zone is being built on the border at Khorgos, just north of the spot where the Ili River crosses into Kazakhstan [22]. Further development of this infrastructure will have mixed impacts, on the one hand placing new stresses on water and other natural resources, but on the other, strengthening the sense of a shared future for the two countries. Announcement of a joint diversion project along the Khorgos River in 2011 is a good sign of what could become convergence on the issue of water.

Terminal Lake Balkhash is the bellwether for the Ili River basin, and its status depends on levels and seasonality of flows below Kapchagai dam. Although the lake is not in the pristine 
condition that preceded anthropogenic pressures, its current status is regarded as fairly stable. A rise or fall of the lake's surface level by just one meter is nevertheless the margin of safety that keeps the lake from being significantly harmed. The lake's equilibrium is being maintained, even though annual flow rates in the lower Ili River have fluctuated significantly in recent years (Figure 2). This implies that the ecosystem is resilient, but should the margin of safety be exceeded and the lake's surface again fall, Lake Balkhash would likely catastrophically fragment into smaller bodies of water [23]. This in turn would accelerate the processes of desertification and degradation of the delta and other riparian ecosystems dependent on the lake.

There have been calls to modernize the entire water management system in the Ili-Balkhash basin, with emphasis on climate-smart, water-saving technologies--especially for irrigation systems, which consume the greatest share of the basin's water [24, 25, 26]. These systems have decayed following Kazakhstan's independence in 1991 and are scheduled for modernization [27, 28]. Irrigation efficiencies along the upper reaches of the river in China are somewhat greater than in Kazakhstan but still warrant upgrading [2]. It will be critical for water management entities to avoid the so-called rebound effect as these improvements are made, making sure that "saved" water is not reallocated to expand irrigation into new areas or shifted so that more waterintensive crops can be grown $[29,30]$. Should appropriate policies not be in place, water saving technologies would contribute little or nothing to the environmental flows needed to preserve downstream areas.

\section{References}

1. M.M. Lebedeva, Modern Global Problems of World Politics (Aspect Press, Moscow, 2009) In Russian

2. N. Thevs, S. Nurtazin, V. Beckmann, R. Salmyrzauli, A. Khalil, Water 9, 207 (2017)

3. T. Petr, Int. J. Salt Lake Res. 1, 21 (1992)

4. L. Guo, Z. Xia, H. Zhou, F. Huang, B. Yan., Hydrol. Eng. 20, doi: 10.1061/(ASCE)HE.1943-5584.0001214 (2015)

5. A. Aitzhanova, S. Katsu, J.F. Linn, V. Yezhov, Eds. Kazakhstan 2050. Toward a Modern Society for All (Oxford University Press, Oxford, 2014)

6. Z.D. Dostay, R.I. Galperin, S.K. Davletgaliev, S.A. Alimkulov, Questions Geogr. Geoecol. 4, 18 (2012) In Russian

7 Anonymous. Kazakhstan. (FAO AQUASTAT, Rome). Available online: $\mathrm{http}: / / w w w . f a o . o r g / \mathrm{nr} /$ water/aquastat/countries_regions/KAZ/KAZ-CP_eng.pdf

8. T. Chida, Cahiers du Monde Russe 54, 239 (2013)

9. K. Kezer, H. Matsuyama, Hydrol. Proc. 20, 1407 (2006)

10. M.I. Lomonovicha, Ed. The Ili Valley, Its Nature and Resources (Kazakh Academy of Sciences, Almaty, 1963) In Russian

11. Z.D. Dostaj, E. Giese, W. Hagg. Wasserressourcen und deren Nutzung im Ili-Balchas Becken (University of Giessen, Germany, 2006)

12. T.K. Kudekova, Ed. The Modern Ecological State of the Basin of Lake Balkhash (Kaganat, Almaty, 2002) In Russian

13. T. Akiyama, J. Li, J. Kubota, Y. Konagaya, M. Watanabe, Water Futures 68, 595 (2012)

14. S.A. Abdrisilov, K.A. Tulebaeva, Hydrotech. Construct. 28416 (1994)

15. V.M. Starodubtsev, S.R. Truskavetskiy, Water Resources 38, 253 (2011)

16. C. Mackerras, East Asia 32, 25 (2015)

17. L.F. Spivak, N.R. Muratova, I.S. Vitkovskaya, M.Z. Batyrbaeva, K.U. Alibaev, S.G. Moldazhanov, Water Resources of Central Asia and Their Use, 424 (Institute of Geography, Almaty, 2016) In Russian

18. A.G. Terekhov, S.A. Dolgikh, Water Resources of Central Asia and Their Use, 176 (Institute of Geography, Almaty, 2016) In Russian 
19. S. Ho, Water Int. 42, 142 (2017)

20. D.I. Stewart, Defence Studies 14, 76 (2014)

21. J. Campins Eritja, J. Saura Estapa, X. Pons Rafols, Asian J. Int. Law 6, 119 (2016)

22. D. Arase, Southeast Asian Affairs 25 (2015)

23. T. Christiansen, U. Schöner, Irrigation Areas and Irrigation Water Consumption in the Upper Ili Catchment, NW-China (University of Giessen, Germany, 2004)

24. S. Broka, Å. Giertz, G. Christensen, D. Rasmussen, A. Morgounov, T. Fileccia, R. Rubaiza, Kazakhstan Agricultural Sector Risk Assessment (World Bank, Washington, 2016)

25. A. Franken, Ed. Irrigation in Central Asia in Figures. Aquastat Survey - 2012 (FAO, Rome, 2013)

26. OECD Review of Agricultural Polices: Kazakhstan 2013 (OECD, Paris, 2013)

27. EBRD finances irrigation in three subregions of Kazakhstan. Available online at: http:// www.ebrd.com/news/2017/ebrd-finances-irrigation-in-three-regions-of-kazakhstan.html

28. World Bank to help Kazakhstan modernize irrigation system. Available online at: http:// www.worldbank.org/en/news/press-release/2014/04/29/world-bank-to-help-kazakhstanmodernize-irrigation-system

29. L. Pfeiffer, C.Y.C. Lin, J. Environ. Econ. \& Mgmt. 67, 189 (2014)

30. A. Dumont, B. Mayor, E. López-Gunn, Aquatic Procedia 1, 64 (2012) 